\title{
Application of Sweetwater as Potential Carbon Source for Rhamnolipid Production by Marine Pseudomonas aeruginosa UMTKB-5
}

\author{
Mohamad Azran Faris Mohamad Azemi ${ }^{1}$, Noor Fazielawanie Mohd Rashid ${ }^{1}$, Jasnizat Saidin², \\ Abdul Wahid Mohd Effendy², Kesaven Bhubalan 1, 2, 3* \\ ${ }^{1}$ School of Marine and Environmental Sciences, Universiti Malaysia Terengganu, Terengganu, Malaysia. \\ 2 Institute Marine Biotechnology, Universiti Malaysia Terengganu, Terengganu, Malaysia. \\ ${ }^{3}$ Malaysian Institute of Pharmaceuticals and Nutraceuticals, Penang, Malaysia. \\ * Corresponding author. Tel.: +609-6683945; email: kesaven@umt.edu.my \\ Manuscript submitted January 20, 2016; accepted April 6, 2016. \\ doi: 10.17706/ijbbb.2016.6.2.50-58
}

\begin{abstract}
Rhamnolipid (RL), the major component of biosurfactant is commonly produced via bacterial fermentation from selected carbon sources. Biosynthesis of RL is initiated by nitrogen limitation and presence of excess carbon source. RL is completely biodegradable and non-toxic. Applications of RL include the production of fine chemicals, enhancement of biodegradation, food industries and pharmaceutical products. In this study, efforts were taken to biosynthesize RL using Pseudomonas aeruginosa UMTKB-5 isolated from marine sediment. The bacterium was fed with cane sugar refinery by-product, sweetwater as sole carbon source and 5 different types of nitrogen sources. Three different of carbon to nitrogen $(\mathrm{C} / \mathrm{N})$ ratios were tested in this study. The sweetwater was first characterized for its components. Sweetwater is mainly comprised of water (79.9 wt\%) and glycerol (10.3 wt $\%)$. The total sugar content is $17.4 \mathrm{wt} \%$ and mainly comprises of sucrose, glucose and fructose. Biosynthesis of RL was carried out in $50 \mathrm{~mL}$ shaken-flask cultures, incubated at $30^{\circ} \mathrm{C}$ for $72 \mathrm{~h}$ at $200 \mathrm{rpm}$. Sulfuric acid was used to hydrolyze rhamnose groups of RL in the culture supernatant into methyl furfural. The hydrolyzed sample containing rhamnose was reacted with orcinol (1-3-dihydroxy-5-methylbenzene). The concentration of RL produced was measured spectrometrically at $421 \mathrm{~nm}$. The surface tension was measured using Du Nouy Ring method. The result obtained showed that production of RL using sweetwater was in the range of $42-50 \mathrm{mg} / \mathrm{L}$. The cell biomass was recorded in the range of $329-729 \mathrm{mg} / \mathrm{L}$. The lower surface tension $(47.26 \mathrm{mN} / \mathrm{m})$ activity occurred when ammonium chloride with $\mathrm{C} / \mathrm{N}$ ratio of 35 was applied. The findings of this study demonstrate the potential application of agro-industrial by-product, sweetwater as a renewable carbon feedstock for RL production via bacterial fermentation.
\end{abstract}

Key words: Rhamnolipid, Pseudomonas aeruginosa, sweetwater, cane sugar refinery by-product.

\section{Introduction}

Biosurfactants are reported as the amphipathic compound produced extracellularly by a variety of microorganisms including yeast, bacteria and filamentous fungi [1]. These naturally occurring surface active compounds are getting much attention as an alternative for synthetic surfactant. With regards to its antimicrobial properties, biodegradability, low toxicity as well as ecological acceptability, biosurfactantsoffer several potential industrial applications. Biosurfactants are applied in the food industry, 
cosmetic industries [2], agricultural fields, especially as biological control of pathogens and in accelerating biodegradation of petroleum [3], [4]. Glycolipids and lipopeptides are the most commonly isolated biosurfactants [5]. Rhamnolipid (RL), which belongs to the glycolipids class, is a naturally occurring biosurfactant which is composed of rhamnose sugar molecules and $\beta$-hydroxyl alkanoic acids (lipid). Its amphiphilic property enables the molecules to concentrate at interfaces, thus reducing the surface tension of aqueous media [4]. Jarvis and Johnson (1949) first isolated RL from P. aeruginosa [6].

RL production from Pseudomonas sp. has high surface activity, thus, becoming an attractive target for biotechnology research [7]. The RL produced by $P$. aeruginosa in liquid cultures are mainly rhamnosyl- $\beta$-hydroxydecanol- $\beta$-hydroxydecanoate(mono-RL)

and rhamnosyl-rhamnosyl- $\beta$-hydroxydecanoyl- $\beta$-hydroxydecanoate (di-RLs) [8]. RL biosynthesis generally involved three major parts, which are biosynthesis of a lipid moiety, biosynthesis of sugar moiety and enzymatic reactions [9]. RL biosynthesis begins with the transfer of two rhamnose moieties from TDP-L-rhamnose. For mono-RL synthesis, the enzyme rhamnosyl-transferase 1(Rt 1) catalyzes the rhamnose transfer to $\beta$-hydroxydecanol- $\beta$-hydroxydecanoate. Meanwhile, di-RLs are synthesized by the enzyme rhamnosyl-transferase 2 (Rt 2) from TDP-L-rhamnose and mono-RL $P$. aeruginosa produces RL during stationary growth phase in limiting concentration of nitrogen sources and excess of carbon sources [10]. Previous studies have reported the production of RL by P. aeruginosa using various carbon sources. For example, using vegetable based oils such as, soybean oil [11] and corn oil [12], glycerol [13] as well as industrial by-products or wastes [14].

Although biosurfactant exhibit such important advantages, they are not extensively employed due to the relatively high production cost [15]. Carbon sources are vital for RL production and are one of the high cost absorbing factors. A possible strategy to reduce production cost would be using renewable carbon source such as agro-industrial waste and by-products as a substrate. This study highlights the application of sweetwater, a novel substrate for RL production by a marine isolate, $P$. aeruginosa UMTKB-5.

\section{Methodology}

\subsection{Bacterial Strain and Inoculum Preparation}

P. aeruginosa UMTKB-5 (GenBank accession number: KT194193.1) was previously isolated from marine sediment [16]. P. aeruginosa UMTKB-5 was grown overnight at $30^{\circ} \mathrm{C}$ on nutrient rich (NR) agar. Two loop-full of culture were inoculated in NR medium consisting of the following components: per liter; $10 \mathrm{~g}$ peptone, $10 \mathrm{~g}$ meat extract and $2 \mathrm{~g}$ yeast extract [17]. Approximately $14 \mathrm{~g} / \mathrm{L}$ of bacteriological agar was added for NR agar. Pre-culture was incubated on a reciprocal shaker at $200 \mathrm{rpm}, 30^{\circ} \mathrm{C}$.

\subsection{Characterization of Sweetwater}

The sweetwater was collected from Gula Padang TerapSdn. Bhd. (Kedah, Malaysia). The sweetwater was sent to TPM Biotech Sdn. Bhd. and ITS Testing Services (M) Sdn. Bhd., for sugar content and other analysis.

\subsection{RL Biosynthesis}

Cultivation was carried out in $50 \mathrm{~mL}$ mineral salts medium (MSM), per liter: $2.80 \mathrm{~g}$ of $\mathrm{KH}_{2} \mathrm{PO}_{4}, 3.32 \mathrm{~g}$ of $\mathrm{Na}_{2} \mathrm{HPO}_{4}$ and $0.25 \mathrm{~g}$ of hydrated $\mathrm{MgSO}_{4 .} .7 \mathrm{H}_{2} \mathrm{O}$ using $250 \mathrm{~mL}$ Erlenmeyer flasks [17]. The nitrogen source concentration was fixed at $0.25 \mathrm{~g} / \mathrm{L}$ and the following types were used; $\mathrm{NH}_{4} \mathrm{Cl},\left(\mathrm{NH}_{2}\right) \mathrm{SO}_{4}, \mathrm{NH}_{4} \mathrm{NO}_{3}$, $\mathrm{NH}_{2} \mathrm{CONH}_{2}$ and $\mathrm{NaNO}_{3}$ [18]. Carbon to nitrogen ratios (C/N) of 20 and 35 were applied. Approximately 3.5 $\mathrm{mL}(200 \mathrm{mg} / \mathrm{L})$ of bacteria pre-culture was transferred into $46 \mathrm{ml}$ of MSM supplemented with $1 \mathrm{~mL} / \mathrm{L}$ of trace elements (TE). TE components are as follows: per liter; $0.22 \mathrm{~g} \mathrm{COCl}_{2} \cdot \mathrm{H}_{2} \mathrm{O}, 9.70 \mathrm{~g} \mathrm{FeCl}_{3}, 7.80 \mathrm{~g} \mathrm{CaCl}_{3}$, $0.12 \mathrm{~g} \mathrm{NiCl}_{2} .6 \mathrm{H}_{2} \mathrm{O}, 0.11 \mathrm{~g} \mathrm{CrCl}_{3} .6 \mathrm{H}_{2} \mathrm{O}$ and $0.16 \mathrm{~g} \mathrm{CuSO}_{4} \cdot 5 \mathrm{H}_{2} 0$ [19]. The cultures were incubated at $30{ }^{\circ} \mathrm{C}, 200$ rpm for $72 \mathrm{~h}$. Cells were harvested by centrifuging at $4 \stackrel{\circ}{\circ} \mathrm{C}, 9000 \mathrm{rpm}$ for $5 \mathrm{~min}$ using HIMAC CR $22 \mathrm{~N}$ (Hitachi, 
Tokyo) high-speed refrigerated centrifuge machine. The cell pellets were kept in $-80^{\circ} \mathrm{C}$ deep freezer, MDF-U5537 (Sanyo, Japan). On the other hand, the supernatants were subjected to orcinol assays.

\subsection{Quantification of RL}

The concentration of RL was determined by orcinol assay using the method proposed by [20], [21] with some modifications. Approximately $400 \mu \mathrm{L}$ of culture supernatant was extracted twice with $750 \mu \mathrm{L}$ of diethyl ether. After being a vortex for $3 \mathrm{~min}$, the fractions were evaporated to dryness and $400 \mu \mathrm{L}$ of pH 8 phosphate buffer was added. To $100 \mu \mathrm{L}$ of each sample, $900 \mu \mathrm{l}$ of orcinol reagent $(0.19 \% \mathrm{w} / \mathrm{v}$ of orcinol in $53 \% \mathrm{v} / \mathrm{v}$ of $\mathrm{H}_{2} \mathrm{SO}_{4}$ ) was added. After heating for $30 \mathrm{~min}$ at $80{ }^{\circ} \mathrm{C}$, the samples were cooled at room temperature. The optical density of samples was determined using a spectrophotometer, Varioskan ${ }^{\text {TM }}$ Flash Multimode Reader (Thermo Scientific, USA) at $421 \mathrm{~nm}$. The rhamnolipid concentration was calculated from the standard curve prepared with L-rhamnose and corrected with the multiplication factor, 2.25 [22].

\subsection{Lyophilization and Cell Dry Weight Measurement}

The lyophilization of cell pellets was done using Freezone 4.5 Freezer Dry System (Labconco, USA). Cells were frozen at $-80^{\circ} \mathrm{C}$ was subjected to lyophilization for $72 \mathrm{~h}$ before determining the cell dry weight (CDW). The CDW was measured using a CP 2245 (Sartorius, Germany) electronic balance.

\subsection{Surface Tension Measurement}

The supernatants were then subjected to surface activity measurements using Sigma-701 (Attension, Finland) tensiometer. The Du-Nouy-Ring method was used to measure the surface tension [9]. The procedure was carried out at room temperature.

\subsection{Statistical Analysis}

The data analysis was conducted using the SPSS software (version 20.0). One-way ANOVA was applied to determine any significance difference between nitrogen sources and the RL production. The results are considered significant if $p<0.05$.

\section{Results and Discussion}

\subsection{Characterization of Sweetwater}

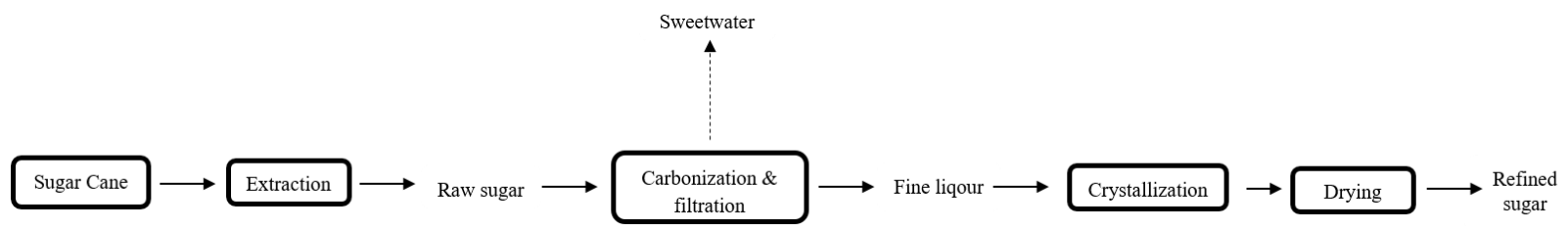

Fig. 1. Cane sugar refinery process.

Sweetwater is one of the main by-products of cane sugar refining process. Sweetwater is also described as water that still contains sucrose from anywhere in the refinery. Based on the sugar refining process (Fig. 1), sweetwater is produced after undergoing carbonization and filtration as waste. Table 1 shows the composition of sugars, glycerol, and water in sweetwater. Sucrose was detected as the highest remaining sugar component with $17.4 \mathrm{wt} \%$. Then former is followed by glucose $(0.6 \mathrm{wt} \%)$ and fructose $(0.4 \mathrm{wt} \%)$. Besides this, glycerol was also recorded in sweetwater with a concentration of $10.3 \mathrm{wt} \%$. Hence, sweetwater is a promising cost-effective carbon feedstock comprising the consortia of carbon sources from the waste. To date, there are few published reports on the usage of sweetwater as a carbon substrate for RL production.The physical parameter of sweetwater is stated in Table 2 . The $\mathrm{pH}$ of sweetwater is acidic but 
the strain was still able to produce RL. The $\mathrm{pH}$ is important parameter because it involves the chemical reactions of the living cells [23]. The previous study showed that the maximum RL production occurred when $\mathrm{pH}$ was in the range of 6 to 6.8 [24]. In addition, sweetwater was able to dissolve completely in liquid (98.90\%). This makes sweetwater a water-soluble substrate.

Table 1. The Components of Sweetwater

\begin{tabular}{lcl}
\hline \multicolumn{1}{c}{ Compositions in sweetwater } & Contents & \multicolumn{1}{c}{ Method } \\
\hline Glucose $(w t \%)^{\mathrm{a}}$ & 0.6 & AOAC 982.14 (HPLC) \\
Fructose (wt\%)a & 0.4 & AOAC 982.14 (HPLC) \\
Sucrose (wt\%) & 17.4 & AOAC 982.14 (HPLC) \\
Glycerol content $(w \mathrm{t} \%)^{\mathrm{b}}$ & 10.3 & Titration \\
Water content (wt\%) & 79.9 & Karl Fischer \\
\hline
\end{tabular}

a Analyzed by TPM Biotech SdnBhd, Malaysia

b Analyzed by ITS Testing Services (M) SdnBhd, Malaysia

Table 2. The Properties of Sweetwater

\begin{tabular}{|c|c|c|}
\hline Test & Value & Method \\
\hline $\mathrm{pH}_{\text {value }}{ }^{\mathrm{a}}$ & 4.86 & AOAC 32.1.20 \\
\hline Solubility test (\%) ${ }^{\mathrm{a}}$ & 98.90 & $\mathrm{QC} / 0054$ \\
\hline Alkalinity as $\mathrm{NaOH}(\% \mathrm{w} / \mathrm{w})^{\mathrm{b}}$ & 0.015 & APHA $2130 \mathrm{~B}$ \\
\hline Specific gravity, $37^{\circ} \mathrm{C}^{\mathrm{b}}$ & 1.078 & ASTM D 1052 \\
\hline Dynamic viscosity, $37^{\circ} \mathrm{C}(\mathrm{mPa} . \mathrm{s})^{\mathrm{b}}$ & 1.36 & Brookfield viscometer \\
\hline Total residue at $160^{\circ} \mathrm{C}(\% \mathrm{w} / \mathrm{w})^{\mathrm{b}}$ & 14.3 & Oven drying \\
\hline
\end{tabular}

a Analyzed by TPM Biotech SdnBhd, Malaysia

b Analyzed by ITS Testing Services (M) SdnBhd, Malaysia

\subsection{Evaluation of Different Nitrogen Sources and C/N Ratio}

Table 3. Production of RL by P. aeruginosa UMTKB-5 Using Different C/N Ratio and Nitrogen Sources ${ }^{a}$

\begin{tabular}{clcc}
\hline $\mathrm{C} / \mathrm{N}$ ratio & \multicolumn{1}{c}{$\mathrm{Nitrogen} \mathrm{sources}$} & $\mathrm{CDW}^{\mathrm{b}}, \mathrm{mg} / \mathrm{L}$ & RL concentrationc, mg/L \\
\hline 20 & $\mathrm{NH}_{4} \mathrm{Cl}$ & $469.0 \pm 10$ & $47.8 \pm 3$ \\
& $\left(\mathrm{NH}_{4}\right)_{2} \mathrm{SO}_{4}$ & $446.0 \pm 30$ & $46.7 \pm 0$ \\
& $\mathrm{NH}_{4} \mathrm{NO}_{3}$ & $499.0 \pm 70$ & $44.6 \pm 3$ \\
& $\mathrm{NH}_{2} \mathrm{CONH}_{2}$ & $329.3 \pm 14$ & $44.3 \pm 2$ \\
& $\mathrm{NaNO}_{3}$ & $476.0 \pm 90$ & $45.8 \pm 2$ \\
35 & $\mathrm{NH}_{4} \mathrm{Cl}$ & $458.0 \pm 80$ & $45.2 \pm 3$ \\
& $\left(\mathrm{NH}_{4}\right)_{2} \mathrm{SO}_{4}$ & $564.0 \pm 60$ & $45.2 \pm 2$ \\
& $\mathrm{NH}_{4} \mathrm{NO}_{3}$ & $723.0 \pm 35$ & $42.8 \pm 1$ \\
& $\mathrm{NH}_{2} \mathrm{CONH}_{2}$ & $666.0 \pm 20$ & $50.1 \pm 6$ \\
& $\mathrm{NaNO}_{3}$ & $535.0 \pm 33$ & $44.1 \pm 4$ \\
& $\mathrm{NH}_{4} \mathrm{Cl}$ & $649.0 \pm 10$ & $45.4 \pm 3$ \\
& $\left(\mathrm{NH}_{4}\right)_{2} \mathrm{SO}_{4}$ & $546.0 \pm 33$ & $45.6 \pm 2$ \\
& $\mathrm{NH}_{4} \mathrm{NO}_{3}$ & $658.0 \pm 88$ & $43.5 \pm 1$ \\
& $\mathrm{NH}_{2} \mathrm{CONH}_{2}$ & $729.0 \pm 52$ & $46.3 \pm 2$ \\
& $\mathrm{NaNO}_{3}$ & $543.0 \pm 21$ & $43.4 \pm 1$
\end{tabular}

$\mathrm{RL}$, rhamnolipid. Data shown are means of triplicates. alncubated for $72 \mathrm{~h}$ at $30^{\circ} \mathrm{C}$ at $200 \mathrm{rpm}$ in MSM, bDried cell pellets was weighed after $72 \mathrm{~h}$ of lyophilization, cRL concentration was quantified using orcinol assays

Here, P. aeruginosa UMTKB-5 was tested for RL production using sweetwater as a sole of carbon source. $P$. aeruginosa is previously known as the primary producer of RL [9]. Several factors are known to influence 
the production of RL including nutritional and environmental parameter [23]. Excess carbon source and limitation of nitrogen sources is the important key in the biosynthesis of RL [9]. Here, effort was taken to evaluate RL production using sweetwater with a combination of different nitrogen sources. The concentration of nitrogen sources was fixed to $0.25 \mathrm{~g} / \mathrm{L}$ of concentration. Results of the different $\mathrm{C} / \mathrm{N}$ ratio are stated in Table 3. The RL production was in the range of $42-50 \mathrm{mg} / \mathrm{L}$. However, the one-way ANOVA testproves that there was no significance different in the RL concentrations from three different $\mathrm{C} / \mathrm{N}$ ratios, $p=0.183,(p>0.05)$.

It is important to study $\mathrm{C} / \mathrm{N}$ ratio as it is known to play an important role in optimizing RL production [24]. Nevertheless, the results prove the ability of $P$. aeruginosa UMTKB-5 to successfully convert sweetwater into RL. As in the previous study of glycolipid biosurfactant production, Kim and coworkers recognized that the organic nitrogen such as urea, $\mathrm{NH}_{2} \mathrm{CONH}_{2}$ give support growth of the cells [25]. Urea was found to promote cell growth as higher cell biomass (Table 3). Increase in CDW was recorded (329$729 \mathrm{mg} / \mathrm{L}$ ) based on different C/N ratios. Fig. 2 illustrates the metabolic pathway of RL [26], [27]. The different carbon components found in sweetwater are isomerized into D-glucose-1-phosphate, the precursor for sugar moiety in RL [9]. On the other hand, lipid moiety is attained from fatty acid de novo synthesis.

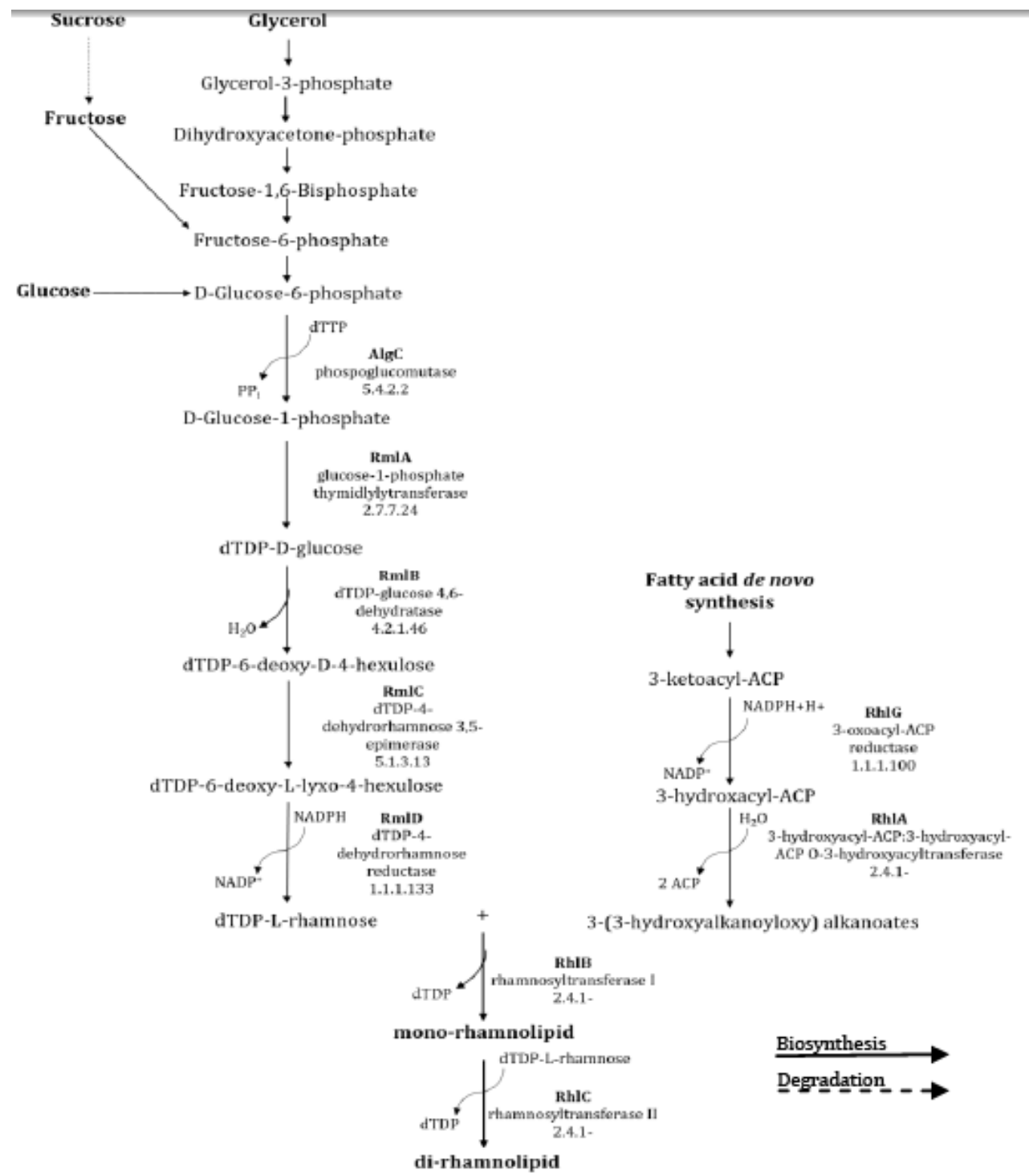

Fig. 2. RL biosynthesis pathway in P. aeruginosa. 


\subsection{Surface Tension of RL Produced from Sweetwater}

The distilled water was selected as negative control in conducting surface tension measurement of RL produced by P. aeruginosa UMTKB-5. The surface tension of water is $72 \mathrm{mN} / \mathrm{m}$ [28]. All of the RLs produced from different nitrogen sources with different $\mathrm{C} / \mathrm{N}$ ratio showed a sharp decrease in surface tension when compared with the control (Fig. 3). The range of surface tensions measured was between $47-59 \mathrm{mN} / \mathrm{m}$. The lowest surface tension of $47.26 \mathrm{mN} / \mathrm{m}$ was recorded when $\mathrm{NH}_{4} \mathrm{Cl}$ used as nitrogen source with $\mathrm{C} / \mathrm{N}$ ratio of 35. The surface activity is the crucial properties of surfactant [29]. This phenomenon occurs when the surfactant is able to decrease the intermolecular force between molecules of liquid [29]. Biosurfactant like RL with high surface activity can be utilized in various application including enhancement of biodegradation, food industry, cosmetic and pharmaceutical applications that are related with surface chemistry [30]-[32]. Efforts are being taken to well document the production and characteristics of the RL produced, in order to suffice commercial interest. Studies on the optimization of RL using statistical approach has been carried out [33]. The characterization of the RL congeners using mass spectrometry is also considered important as different mono-RL and di-RL might affect emulsification property and antimicrobial activity [34], [35].

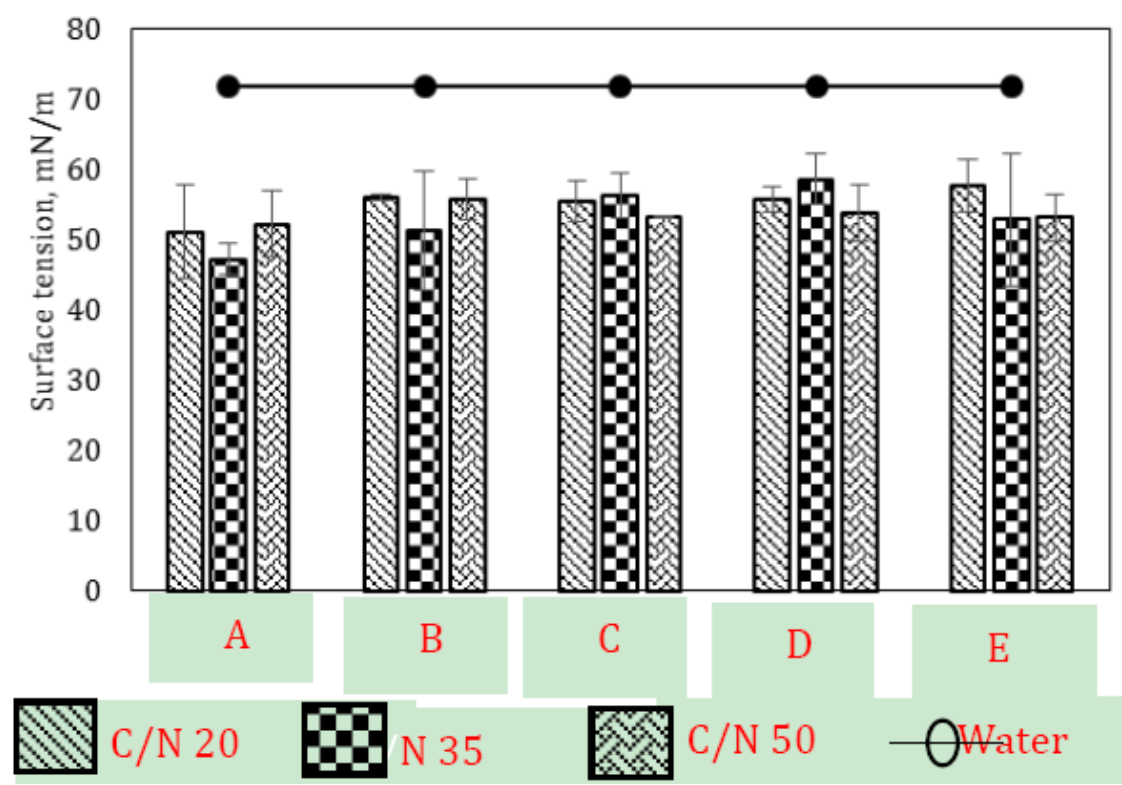

Fig. 3. Surface tension activity of $\mathrm{RL}$ based on the different $\mathrm{C} / \mathrm{N}$ ratio. $\mathrm{A}: \mathrm{NH}_{4} \mathrm{Cl}$; $\mathrm{B}$ : $\left(\mathrm{NH}_{4}\right)_{2} \mathrm{SO}_{4} ; \mathrm{C}_{\mathrm{N}} \mathrm{NH}_{4} \mathrm{NO}_{3}$; D: $\mathrm{NH}_{2} \mathrm{CONH} 2$; E: $\mathrm{NaNO}_{3}$.

\section{Conclusion}

Based on the findings, it can be concluded that sweetwater could be a potential substrate for RL production. Application of this agro-industrial by-product as carbon feedstock could reduce the overall cost of RL production. The bioconversion of waste to wealth is a promising approach in development of sustainable biotechnological processes.

\section{Acknowledgment}

We would like to thank Mr. Mohd. Sofiudin Ismail from Gula Padang TerapSdn. Bhd. (14006-V), Kuala Nerang, Kedah, Malaysia, for providing the cane sugar refinery by-products (sweetwater). This study was supported by the Exploratory Research Grant Scheme (ERGS) [ERGS/1/2013/STG07/UMT/03/02] 
awarded by Ministry of Higher Education, Malaysia.

\section{References}

[1] Chen, S. Y., Wei, Y. H., \& Chang, J. S. (2007). Repeted pH- stat fed-batch fermentation for rhamnolipid production with indigenous Pseudomonas aeruginosa S2. Applied Microbiology and Biotechnology, 76(1), 67-74.

[2] Desai, J. D., \& Banat, I. M. (1997). Microbial production of surfactants and their commercial potential. Microbiology and Molecular Biology Reviews, 61, 47-64.

[3] Grishchenkov, V. G., Townsend, R. T., Mcdonald, T. J., Autenrieth, R. L., Bonner, J. S., Boronin, A. M., et al. (2000). Degradation of petroleum hydrocarbons by facultative anaerobic bacteria under aerobic and anaerobic conditions. Process Biochemistry, 35, 889-896.

[4] Nayak, A. S., Vijaykumar, M. H., \& Karegoudar, T. B. (2008). Characterization of biosurfactant produced by Pseudoxanthomonas sp. PNK-04 and its application in bioremediation. International Biodeterioration \& Biodegradation, 63, 73-79.

[5] Saravanan V., \& Vijayakumar, S. (2012). Isolation and screening of biosurfactant producing microorganisms from oil contaminated soil. Journal of Academic Industry and Research, 1(5), 264-268.

[6] Jarvis, F. G., \& Johnson, M. J. (1949). A glyco-lipid produced by Pseudomonas aeruginosa. Journal American Chemistry Society, 71, 4124-4126.

[7] Reis, R. S., Pereira, A. G., Neves, A. G., \& Freire, D. C. M. (2011). Gene regulation of rhamnolipid production in Pseudomonas aeruginosa. A Review. Bioresource Technology, 102, 6377-6384.

[8] Ochsner, U. A. \& Reiser, J. (1995). Autoinducer-mediated regulation of rhamnolipidbiosurfactant synthesis in Pseudomonas aeruginosa. Proceedings of the National Academy of Science: Vol. 92. (pp. 6424-6428).

[9] Abdel-Mawgoud, A. M., Hausman, R., Lepine, F., Muller, M. M., \& Deziel, E. (2011). Rhamnolipids: detection, analysis, biosynthesis, genetic regulation, and bioengineering of production. Biosurfactants : From Genes to Applications. Microbiology Monographs, 20, 13-55.

[10] Govindammal, M. (2014). Effect of carbon and nitrogen sources on the production of biosurfactant by Pseudomonas fluorescens isolated from mangrove ecosystem. International Journal of Pharmaceutical \& Biological Archives, 5(2), 108-115.

[11] Lang, S., \& Wulllbrandt, D. (1999). Rhamnose lipids-biosynthesis, microbial production and application potential. Applied Microbiology and Biotechnology, 51, 22-32.

[12] Linhardt, R. J., Bakhit, R., Daniels, L., Mayerl, F., \& Pickenhagen, W. (1989). Microbially produced rhamnolipid as a source of rhamnose. Biotechnology and Bioengineering, 33, 365-368.

[13] Saikia, R. R., Deka, S., Deka, M., \& Banat, I. M. (2011). Isolation of biosurfactant-producing Pseudomonas aeruginosa RS29 from oil-contaminated soil and evaluation of different nitrogen sources in biosurfactant production. Annals of Microbiology, 62, 753-763.

[14] Saisa-Ard, K., Maneerat, S., \& Saimmai, A. (2013). Isolation and characterization of biosurfactant-producing bacteria isolated from palm oil industry and evaluation for biosurfactants production using low-cost substrates. Journal of Biotechnology, Computational Biology and Bionanotechnology, 94(3), 275-284.

[15] Thavasi, R., Jayalakshmi, S. \& Banat, I. M. (2010). Biosurfactants from marine bacterial isolates. Current Research, Technology and Education Topics in Applied Microbiology and Microbial Biotechnology, 1367-1373.

[16] Azran, M. F. M. A., Fazielawanie, N. M. R., Saidin, J., Wahid, M. E. A., \& Bhubalan, K. (2014). Bioconversion of cane sugar refinery by-products into rhamnolipid. Proceedings of International Conference on 
Beneficial Microbes (pp. 259-262).

[17] Doi, Y., Kitamura, S., \& Abe, H. (1995). Microbial synthesis and characterization of poly(3-hydroxybutyrate-co-3-hydroxyhexanoate). Macromolecules, 28, 4822-4828.

[18] Rashedi, H., Jamshidi, E., Mazaheri, A. M., \& Bonakdarpour, B. (2005). Isolation and production of biosurfactant from Pseudomonas aeruginosa isolated from Iranian southern wells oil. International Journal of Environmental Science and Technology, 2, 121-127.

[19] Sudesh, K., Few, L. L., Azizan, M. N. M., Majid, M. I. A., Samian, M. R., Najimudin, N., et al. (2004). Biosynthesis and characterization of polyhydroxyalkanoate blends accumulated by Pseudomonas sp. USM 4-55. Journal of Biosciences, 15(2), 15-28.

[20] Chandrasekaran, E. V., \& Bemiller, J. N. (1980). Constituent analyses of glycosaminoglycans. Methods in Carbohydrate Chemistry, pp. 89-96. Academic Press, New York.

[21] Koch, A. K., Kappeli, O., \& Fiechter, A. (1991). Hydrocarbon assimilation and biosurfactant production in Pseudomonas aeruginosa mutants. Journal of Bacteriology, 173(3), 4212-4219.

[22] Deziel, E., Lepine, F., Milot, S., \& Villemur, R. (2000). Mass spectrometry monitoring of rhamnolipids from a growing culture of Pseudomonas aeruginosa strain 57RP. Biochimicaet Biophysica Acta, 1485, 145-152.

[23] Irfan, M. M., \& Jamal, A. (2011). Factors affecting the rhamnolipidbio surfactant production. Pakistan Journal of Biotechnology, 8(1), 1-5.

[24] Guerra-Santos, L. H., Kappeli, O., \& Fiechter, A. (1986). Dependence of Pseudomonas aeruginosa continuous cultures biosurfactants production on nutritional and environmental factor. Applied Microbiology and Biotechnology, 24, 443-448.

[25] Kim, H. S., Jeon, J. W., Kim, B. H., Ahn, C. Y., Oh, H. M., Yoon, B. D., et al. (2006). Extracellular production of a glycolipid biosurfactant, mannosylerythritol lipid, by Candida sp. SY16 using fed-batch fermentation. Applied Microbiology and Biotechnology, 70, 391.

[26] Soberon-Chavez, G., Lepine, F., \& Deziel, E. (2005). Production of rhamnolipids by Pseudomonas aeruginosa. Applied Microbiology and Biotechnology, 68, 718-725.

[27] Wittgens, A., Tiso, T., Arndt, T. T., Wenk, P., Hemmerich, J., Muller, C., et al. (2011). Growth independent rhamnolipid production from glucose using the non-pathogenic Pseudomonas putida KT2440. Microbial Cell Factories, 10, 1-17.

[28] Willumsen, P., \& Karlson, U. (1997). Screening of bacteria, isolated from PAH-contaminated soils, for production of biosurfactants and bioemulsifiers. Biodegradation, 7(5), 415-423.

[29] Satpute, S. K., Banpurkar, A. G., Dhakephalkar, P. K., Banat, I. M., \& Chopade, B. A. (2010). Methods for investigating biosurfactants and biomulsifiers: A review. Critical Reviews in Biotechnology, 1-18.

[30] Zhang, Y., \& Miller, R. M. (1994). Effect of a Pseudomonas rhamnolipidbio surfactant on cell hydrophobicity and biodegradation of octadecane. Applied and Environmental Microbiology, 60(6), 2101-2106.

[31] Nitschke, M., \& Costa, S. G. V. A. 0. (2007). Biosurfactant in food industry. Trends in Food Science \& Technology, 18(5), 252-259.

[32] Abalos, A., Pinazo, A., Infante, M. R., Casals, M., Garcia, F., Manresa, A., et al. (2001). Physicochemical and antimicrobial properties of new rhamnolipids produced by Pseudomonas aeruginosa AT10 from soybean oil refinery wastes. Langmuir, 17, 1367-1371.

[33] Shan, Y. C., Wei, B. L., Yu, H. W., Wen, M. C., \& Jo, S. C. (2007). Improved production of biosurfactant with newly isolated Pseudomonas aeruginosa S2. Biotechnology Progress, 23, 661-666.

[34] Yin, H., Qiang, J., Jia, Y., Ye, J., Peng, H., Qin, H., Zhang, N., He, B., et al. (2009). Characteristics of biosurfactant produced by Pseudomonas aeruginosa S6 isolated from oil-containing wastewater. 
Process Biochemistry, 44, 302-308.

[35] Das, P., Yang, X. P. \& Ma, L. Z. (2014). Analysis of biosurfactants from industrially viable Pseudomonas strain isolated from crude oil suggests how rhamnolipids congeners affect emulsification property and antimicrobial activity. Frontiers in Microbiology, 5, 1-8.

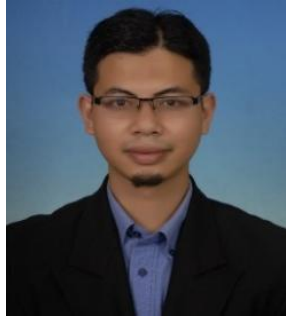

bioprocess.
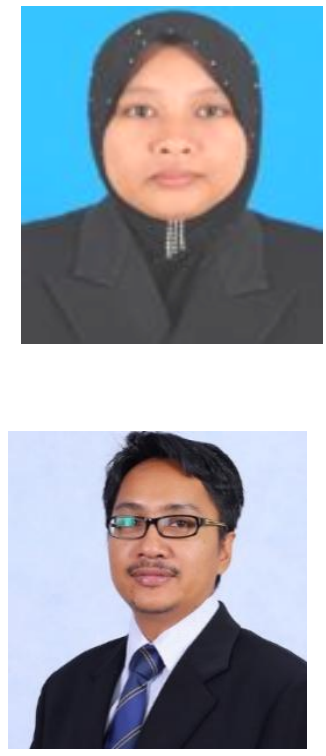

Jasnizat Saidin is a lecturer at the School of Marine and Environmental Sciences, UMT. He received his bachelor of science degree in biotechnology from UPM and his master's degree in marine biotechnology from UMT. His doctorate in microbiology was from Universite de Bretagne Sud, France in marine biology. In addition to teaching marine biotechnology, Dr. Jasnizat is a researcher in Institute of Marine Biotechnology (IMB), UMT. His research interests are in marine biotechnology, especially in natural product from marine microorganisms.

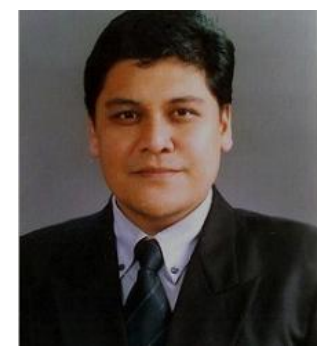

Abdul Wahid Mohd Effendy completed obtained his doctorate in veterinary immunopathology in 1998 from UPM. He did his post-doctorate on disease diagnosis at Chonnam National University, South Korea under KISTEP programme in 2003. He is actively engaged in research activities on immunology, microbiology, animal pathology. He is the author of many high impact research articles and had received numerous awards of merit from local and international agencies. He attained his professorship in 2009 and has been working at IMB, UMT. He is currently appointed as the deputy vice chancellor (research and innovation), UMT.

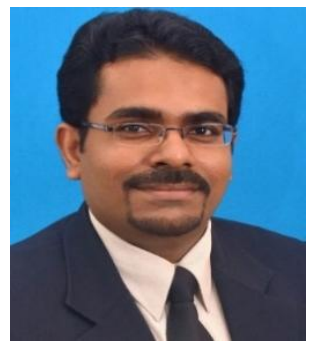

Kesaven Bhubalan completed obtained his doctorate in microbial biotechnology in 2010 from UniversitiSains Malaysia. He is actively engaged in research activities on biopolymers and microbial genetics and teaches marine and biotechnology based subjects for undergraduate students. He is the author of several research articles and chapters in books. He is currently working as a lecturer in UMT and has been appointed as a research fellow at the Malaysian Institute of Pharmaceuticals and Nutraceuticalsas an associate fellow at IMB, UMT. 